\section{Bozhanova V., Kononova O., Bondarenko K.}

\title{
ESSENCE AND BASIC STAGES OF THE CONSTRUCTION COMPANY STRATEGIC MANAGEMENT
}

Досліджено теоретико-методологічні положення та практичні аспекти здійснення процесу стратегічного управління будівельною компанією. Вивчено сутність поняття «стратегічне управління» та визначені основні етапи стратегічного управління будівельним підприємством. Стратегічне управління являє собою по суті одну з функцій управління, яка зводиться до вибору основних иілей діяльності будівельної компанї та шляхів їх досягнення.

Ключові слова: стратегічне управління, аналіз середовища, вибір стратегї, виконання стратегї, будівельне підприємство.

\section{Introduction}

Today, there is no doubt that a good performance achieves continuous improvement in only those organizations, where every employee gives his best achievement priority to corporate goals and business strategy.

Strategy, in the most general terms, is an action plan to achieve those objectives. Strategic management is an ongoing, dynamic and sequential process, by which organization adapts in time to the external environment changes and effectively utilizes its existing potential.

Now it becomes more and more obvious that the main feature of the construction company management under market conditions is their long-term outlook orientation, that is, management of fundamental researches, diversification of operations, innovative activities and maximal use of creative efforts of the personnel. The experience of the advanced nations shows that the effective solution of all the above-listed tasks is impossible without the strategic management.

\section{The object of research and its technological audit}

In order to effectively form of the strategic management essence the term «strategic management» in the theory and practice of the management was conducted, which allowed to designate the boundary between the current and mediumdated management at the level of production and the management at the highest level, as well as to take into account changes in surroundings and the dynamics of the transformation of economic relations in the competitive environment.

\section{The aim and objectives of research}

The aim of the article is examination of the words and terms making up its title and presents them in a way intended to make them useful tools for those charged with related duties.

Based on the foregoing, one can formulate the task of the investigation, which is:

1. To clarify the essence of the construction company strategic management.
2. To disclose the basic stages of the construction company strategic management.

\section{Research of existing solutions of the problem}

The development of theoretical, methodological and practical matters related to the formation and implementation of the production company strategic management was reflected in the works of the following scientists [1-19].

Author of Strategy and Structure [20], the classic study of the relationship between an organization's structure and its strategy, defined strategy as «the determination of the basic long-term goals and objectives of an enterprise, and the adoption of courses of action and the allocation of resources for carrying out these goals».

Author of Planning and Control Systems [21], one of the books that laid the foundation for strategic planning, didn't give his own definition of strategy. Instead, he used one presented in an unpublished paper by Harvard colleague Kenneth R. Andrews: «the pattern of objectives, purposes or goals and major policies and plans for achieving these goals stated in such way as to define what business the company is or is to be in and the kind of company it is or is to be».

A co-founder of the California Management Review, and author of the 1979 «bible», Strategic Planning [22]: What Every Manager Must Know, observed that there was little agreement on terms or definitions and confined his discussion of the definition of strategy to a lengthy footnote. But, nowhere does he define strategy in straightforward terms.

Another Harvard professor [23] became well known with the publication of his 1980 book, Competitive Strategy. Porter defined competitive strategy as «a broad formula for how a business is going to compete, what its goals should be, and what policies will be needed to carry out those goals». In contrast with Andrews' definition, Porter's is much narrower, focusing as it does on the basis of competition.

In 1994, [13], an iconoclastic professor of management at McGill University, took the entire strategic planning establishment to task in his book, The Rise and Fall of Strategic Planning. In effect, Mintzberg declared strategy did indeed have several meanings, all of which were useful. He indicated that strategy is a plan, a pattern, a position, 
a perspective and, in a footnote, he indicated that it can also be a ploy, a maneuver intended to outwit a competitor.

\section{Methods of research}

The following methods were used to solve the tasks: analysis and synthesis, logical generalization, analogies, comparative comparison, monographic and graph-analytical methods.

\section{Research results}

The introduction of the term «strategic management» to the theory and practice of the management has allowed to designate the boundary between the current and medium-dated management at the level of production and the management at the highest level, as well as to take into account changes in surroundings and the dynamics of the transformation of economic relations in the competitive environment.

The leading idea, which reflects the need to use, along with the tactical and operational management, the ideology of the strategic management, was the idea of the need to transfer the focus of the attention of the company senior management from internal problems that can be coped with by the middle management to the problems of the external environment, that is, to those problems, which can carry either additional possibilities, or additional threats in the future. The reason for this transfer was the desire of the senior management to be able to timely and adequately respond to possible changes in the external environment for its own benefit.

The term «strategic management» was put into use at the turn of 60-70 years. The development of ideas of the strategic management was reflected in the works of such authors as [1-4, 24-27]. The leading idea that reflects the essence of the transition from the operational management to the strategic one is an idea of the need to transfer the focus of the senior management's attention to the external environment in order to respond, in the proper and timely manner, to changes, which take place in it [7, 24].

In the conditions of Russian and domestic reality, the beginning of the development of the strategic management theory refers to the later period - to the late 90 -s years $[8,16,28]$.

One can indicate several constructive definitions that were suggested by authoritative developers of the strategic management theory. Shendel and Hatten considered it as «the process of identifying and establishing the connection of the construction company with its surroundings, which consists of the implementation of selected targets and the attempt to achieve the desired state of mutual relations with surroundings using the allocation of resources that allow the construction company and its divisions to effectively and efficiently operate» [25]. According to Higgens, «the strategic management is a management process to carry out the mission of the construction company using the management of its interaction with surroundings» [26]; Pierce and Robinson define the strategic management «as a set of decisions and actions for the formulation and implementation of strategies developed to achieve the targets of the organization» [27].

In the understanding of Russian and domestic scientists, «the strategic management is a management of the com- pany, which relies on the human potential as a basis of the organization, orients production activities to needs of consumers, flexibly responds and makes in the organization timely changes that meet challenges on the part of surroundings and allow to achieve competitive benefits, cumulatively enabling the company to survive on the long-term horizon, while achieving its targets». In other words, the strategic management is a management that, relying on the human potential and orienting its activities to consumers' needs, allows the organization to survive in the long run.

In this case, the strategic management can be considered as a dynamic set of five interrelated management processes $[7,8]$. These processes logically emerge (or follow) from one another. However, there is a stable feedback and, accordingly, the reverse effect of each process on other ones and on their entire set. This is the important feature of the strategic management structure. The stages of the strategic management are schematically illustrated in Fig. 1.

\begin{tabular}{|c|}
\hline $\begin{array}{l}\text { I stage } \\
\text { Analysis of environment }\end{array}$ \\
\hline $\begin{array}{c}\text { II stage } \\
\text { Determination of targets }\end{array}$ \\
\hline $\begin{array}{c}\text { III stage } \\
\text { Strategy selection }\end{array}$ \\
\hline $\begin{array}{c}\text { IV stage } \\
\text { Strategy implementation }\end{array}$ \\
\hline $\begin{array}{c}\text { V stage } \\
\text { Assessment and control over } \\
\text { implementation }\end{array}$ \\
\hline
\end{tabular}

Fig. 1. Stages of the strategic management

One of the key roles of any management is keeping a balance of the construction company interaction with the external environment.

In this case, it will be involved in the following three processes:

- Obtainment of resources from the external environment (input);

- Conversion of resources into construction products (production);

- Transfer of construction products received to the external environment (output).

The management is meant to ensure the balance between the input and output. The modern market has sharply enhanced the value of the output process in keeping this balance. This precisely reflects in the fact that in the strategic management structure the first stage is the analysis of the environment.

I stage. The analysis of the environment involves the study of three of its components: macro-environment, immediate environment and internal environment of the company. The analysis of the external environment (macroand immediate environment) is aimed at the clarification of what the construction company can expect, if it is in successful operation, and of what complications can await it, if it is unable to timely prevent negative outbursts, which can be given to it by dynamic surroundings.

The analysis of the macro-environment includes studying the impact of the economy, legal regulation and management, 
political processes, natural environment and resources, social and cultural components of society, scientific-technical and technological development of society, infrastructure, etc.

The immediate environment is analyzed according to the following main components: customers and buyers, suppliers, competitors, labor market.

The analysis of the internal environment unveils the possibilities and potential, which can be expected by the construction company in the competitive struggle while achieving its targets. The analysis of the internal environment also allows to better understand the targets of the company and to more precisely formulate the task, that is, to determine the content and directions of the construction company activities. It is extremely important to always remember that the company not only manufactures products for surroundings, but also enables its members to exist, giving the work to them and opportunities to participate in profits, as well as providing them with social guarantees, etc.

The internal environment is analyzed in the following areas:

- human resources of the construction company, their potential, qualification, interests;

- management organization;

- production, which includes organizational, operational, technical and process characteristics, as well as scientific researches and developments;

- finances of the construction company;

- marketing;

- organizational culture.

II stage. The determination of tasks and targets of the construction company, which is considered as one of the stages of the strategic management, usually consists of three sub-stages, each requiring a large and exclusively responsible work. The first sub-stage is setting a task of the construction company, which expresses, in the concentrated form, the essence of existence of the construction company and its purpose. This task gives originality to the construction company and fills the work of people with a special content.

Then, after setting of tasks, there is a sub-stage determination of long-term targets. And this part of the strategic management ends with the sub-stage of breakdown of long-term targets into sub-targets and with the establishment of short-term targets. Setting of tasks and forming of targets of the construction company lead to that it is clear, for what the company functions and for what it strives.

III stage. The strategy is selected after the tasks are set and the targets are determined. At this stage, the decision is made on how and by what means the construction company will strive for the achievement of the targets. The process of the strategy development is rightfully deemed the core of the strategic management. It should be borne in mind that the strategy determination is not a preparation of a plan of actions. The strategy determination is a process of making decision on what to do with each particular area of activities, how and in what direction to develop, what place to occupy on the market, etc.

IV stage. The implementation of the strategy lies in the fact that it is not a process of its realization, but only creates a platform for the realization of the strategy and achievement of the set targets by the construction company. There are very often cases when construction companies are found not to be able to implement the selected strategy. This is usually connected with the fact that either they have made the wrong analysis and incorrect conclusions, or unforeseen changes occurred in the external environment. However, the strategy is often not implemented, because the management cannot properly involve the potential available in the construction company for the implementation of the strategy. This is especially pertained to the use of the human potential.

The main task of the strategy implementation stage is creation of necessary preconditions for the successful realization of the strategy. Therefore, the strategy implementation comes down to effecting strategic changes in the company that transfer it to the state, in which the organization is ready to implement the strategy in life.

If unforeseen changes arise, in surroundings of the construction company there is the stage of adaptation of the selected strategy by changing its local sub-targets, being set with consideration of the strategic targets and changes that have occurred in the environment.

V stage. The assessment and control over the strategy implementation are the logical final stage being carried out in the strategic management. This stage ensures the stable feedback between the process of achieving the targets and targets themselves that face the construction company.

The main tasks being solved in the process of control over the progress of the strategy implementation can include the following:

- definition of what and by what to check the indicators;

- assessment of the state of the controlled object in accordance with the accepted standards, regulations or other benchmarking indicators;

- clarification of reasons for deviations, if such are disclosed as a result of the taken assessment;

- adjustment, if necessary and possible.

In case of control over the strategy implementation, these tasks acquire the well-defined specifics conditioned by the fact that the strategic control is aimed at the clarification of how far the strategy realization leads to the achievement of the construction company targets. It essentially distinguishes the strategic control from the management or operational control, as it is not interested in the accuracy of the strategy implementation or correctness of performing individual works, functions and operations. The strategic control is focused on clarifying whether it is possible to further implement the adopted strategy in the chosen way, and whether its implementation will lead to the achievement of the set targets. The adjustment based on results of the strategic control can have relation to both the strategy realized and targets of the construction company.

The strategic control also investigates, how justified is the use of the strategic management for the development of the contraction company in dynamic market conditions.

\section{SWOT-analysis of research results}

Strengths. The strong side in the conducted research is the strategic management that can be considered as a dynamic set of five interrelated management processes: analysis of environment, determinations of targets, strategy selection, strategy implementation and assessment and control over implementation. 
Weaknesses. The weak side is that the process of the strategy development is rightfully deemed the core of the strategic management. It should be borne in mind that the strategy determination is not a preparation of a plan of actions, therefore, it is necessary to give this stage the greatest amount of time.

Opportunities. Possibilities for further research are the strategic control of the strategic management for the development of the contraction company in dynamic market conditions.

Threats. Threats to the results of the research is that on stage IV there are very often cases when construction companies are found not to be able to implement the selected strategy. This is usually connected with the fact that either they have made the wrong analysis and incorrect conclusions, or unforeseen changes occurred in the external environment.

\section{Conclusions}

1. The essence of strategic management is clarified: it is the process where managers establish an organization's long-term direction, set the specific performance objectives, develop strategies to achieve these objectives in the light of all the relevant internal and external circumstances, and undertake to execute the chosen action plans.

2. Set of five strategic management stages is identified: analysis of environment, determinations of targets, strategy selection, strategy implementation and assessment and control over implementation.

The strategic management is essentially one of the management functions, which is down to selecting the main targets of the construction company activities and ways to achieve them. Therefore, the strategic management becomes today more and more currently important for domestic companies that enter into competition among themselves and with foreign corporations.

\section{References}

1. Ackoff, R. L. Creating the Corporate Future: Plan or be Planned For [Text] / R. L. Ackoff. - John Wiley \& Sons, Inc., 1981. $321 \mathrm{p}$

2. Alekseeva, M. M. Planirovanie deiatel'nosti firmy [Text]: Handbook / M. M. Alekseeva. - Moscow: Finansy i statistika, 2003. - 176 p.

3. Ansoff, H. I. Strategic Management [Text]/H. I. Ansoff. - Palgrave Macmillan UK, 1979. - 236 p. doi:10.1007/978-1-349-02971-6

4. Ansoff, H. I. The New Corporate Strategy, Revised Edition [Text] / H. I. Ansoff. - Wiley, 1988. - 288 p.

5. Afanasiev, M. P. Marketing: strategiia i praktika firmy [Text] M. P. Afanasiev. - Moscow: Finstatinform, 1998. - 104 p.

6. Blank, I. A. Investitsionnyi menedzhment [Text] / I. A. Blank. Kyiv: MP «Item» LTD, 1995. - 448 p.

7. Bowman, C. Strategic Management [Text] / C. Bowman, D. C. Asch. - Palgrave, 1987. - 424 p.

8. Vihanskii, O. S. Strategicheskoe upravlenie [Text] / O. S. Vihanskii. - Moscow: Gardarika, 2009. - 164 p.

9. Vihanskii, O. S. Menedzhment [Text]: Handbook / O. S. Vihanskii, A. I. Naumov. - Ed. 3. - Moscow: Ekonomist, 2003. $528 \mathrm{p}$

10. Gusev, Yu. V. Strategiia razvitiia predpriiatii [Text] / Yu. V. Gusev. - St. Petersburg: SPbUEF, 2002. - 127 p.

11. Karlof, B. Business Strategy [Text] / B. Karlof. - Palgrave Macmillan UK, 1989. - 166 p. doi:10.1007/978-1-349-11265-4

12. King, W. R. Strategic Planning and Policy [Text] / W. R. King, D. I. Cleland. - Van Nostrand Reinhold Company, 1978. - 374 p.

13. Mintzberg, H. Strategy Safari: A Guided Tour Through The Wilds of Strategic Management [Text] / H. Mintzberg, J. Lampel, B. Ahlstrand. - Free Press, 2005. - 416 p.
14. Nozdreva, R. B. Marketing: kak pobezhdat' na rynke [Text] / R. B. Nozdreva, L. I. Tsygichko. - Moscow: Finansy i statistika, 1991. - 304 p.

15. Petrov, A. N. Strategicheskii menedzhment [Text] / ed. by A. N. Petrov. - Ed. 2. - St. Petersburg: Piter, 2008. - 496 p.

16. Raiffa, H. Decision Analysis: Introductory Lectures on Choices Under Uncertainty [Text] / H. Raiffa. - Longman Higher Education, 1968. - $310 \mathrm{p}$

17. Sterlin, A. R. Strategicheskoe planirovanie v promyshlennyh korporatsiiah SShA: opyt razvitiia i novye iavleniia [Text] / A. R. Sterlin, I. V. Tulin. - Moscow: Nauka, 1990. - 198 p.

18. Waterman, R. The Renewal Factor. How the Best Get and Keep the Competitive Edge [Text] / R. Waterman. - Bantam, 1988. - 338 p.

19. Yarovenko, S. M. Metodologicheskie podhody k strukturnym preobrazovaniiam v kapitalnom stroitelstve [Text] / S. M. Yarovenko, K. A. Psarev // Ekonomika stroitelstva. - 1997. - No. 9.

20. Strickland, A. J. Strategic Management: Concepts and Cases [Text] / A. J. Strickland, A. A. Thompson. - Ed. 6. - Irwin Professional Publishing, 1992. - 1088 p.

21. Jincharaje, A. K. Marketing: tolkovyi terminologicheskii slovarspravochnik [Text] / A. K. Jincharaje. - Moscow: Infokont, 1991. - $222 \mathrm{p}$

22. Schendel, D. E. Business Policy or Strategic Management: A Broader View for an Emerging Discipline [Text] / D. E. Schendel, K. J. Hatten // Academy of Management Proceedings. - 1972. Vol. 1972, No. 1. - P. 99-102. doi:10.5465/ambpp.1972.4981324

23. Higgins, J. M. Organizational Policy and Strategic Management: Text and Cases [Text] / J. M. Higgins, J. W. Vincze. Dryden Publications, 1986. - 916 p.

24. Pearce, J. Strategic Management [Text] / J. Pearce, R. Robinson. - Ed. 14. - McGraw-Hill Education, 2014. - 880 p.

25. Chandler, A. D. Strategy and Structure: Chapters in the History of the American Industrial Enterprise [Text] / A. D. Chandler. The MIT Press, 1969. - 480 p.

26. Anthony, R. N. Planning and Control Systems: A Framework for Analysis [Text] / R. N. Anthony. - Division of Research, Harvard Business School, 1965. - 180 p.

27. Steiner, G. A. Strategic Planning [Text] / G. A. Steiner. Free Press, 1997. - 400 p.

28. Porter, M. E. Competitive Advantage: Creating and Sustaining Superior Performance [Text] / M. E. Porter. - Free Press, 1998. - 592 p.

\section{ИССЛЕДОВАНИЕ СУЩНОСТИ И ОСНОВНЫХ ЭТАЛОВ}

\section{СТРАТЕГИЧЕСКОГО УЛРАВЛЕНИЯ СТРОИТЕЛЬНОЙ КОМПАНИЕЙ}

Исследованы теоретико-методологические положения и практические аспекты осуществления процесса стратегического управления строительной компанией. Изучена сущность понятия «стратегическое управление» и определены основные этапы стратегического управления строительным предприятием. Стратегическое управление представляет собой по сути одну из функций управления, которая сводится к выбору основных целей деятельности строительной компании и путей их достижения

Ключевые слова: стратегическое управление, анализ среды, выбор стратегии, выполнение стратегии, строительное предприятие.

Bozhanova Viktoriia, Doctor of Economic Sciences, Professor, Department of Management, Project Management and Logistics, Prydniprovs'ka State Academy of Civil Engineering and Architecture, Dnipro,Ukraine,e-mail:vyu7575@gmail.com, ORCID: https:// orcid.org/0000-0002-0595-9347

Kononova Oleksandra, PhD, Associate Professor, Department of Accounting, Economics and Human Resources Management of Enterprise, Prydniprovs'k a State Academy of Civil Engineering and Architecture, Dnipro, Ukraine, e-mail: oleksandrakononova@gmail.com, ORCID: http://orcid.org/0000-0002-7215-8574

Bondarenko Kostiantyn, Department of Management, Project Management and Logistics, Prydniprovs'ka State Academy of Civil Engineering and Architecture, Dnipro, Ukraine, e-mail:ko6tia@gmail.com ORCID: http://orcid.org/0000-0003-2148-4967 